\title{
PELATIHAN KADER POSYANDU DALAM DETEKSI PERKEMBANGAN ANAK USIA DINI
}

\author{
Nur Hayati, Muthmainnah, Arumi Savitri Fatimaningrum \\ PAUD FIP Universitas Negeri Yogyakarta \\ nurhayati@uny.ac.id, diwan_nafil@yahoo.co.id, arumi.fatimaningrum@yahoo.com
}

\begin{abstract}
Abstrak
Upaya pemantauan tumbuh kembang anak usia dini secara pokok merupakan tugas keluarga dan dibantu oleh kader Posyandu melalui kegiatan Posyandu. Program Posyandu dilakukan di setiap desa oleh kader yang telah diberi pengetahuan dan pelatihan oleh para petugas kesehatan untuk memasyarakatkan pengetahuan tentang kesehatan, terutama pertumbuhan dan perkembangan anak pada para orang tua. Umumnya kegiatan Posyandu meliputi kegiatan penimbangan balita dan pemberian nutrisi, sehingga sebagai sasaran utama Posyandu lebih tertuju pada tahap pertumbuhan fisik saja. Oleh karena itu, perlu adanya pemberian pengetahuan pada kader Posyandu tentang deteksi dini perkembangan anak, sehingga tindakan preventif dapat dilakukan untuk mengatasi adanya gangguan perkembangan pada balita. Pada program pelatihan peran kader Posyandu ini dapat terlaksana dengan melibatkan 80\% kader Posyandu di kecamatan Pleret Bantul yang diikuti oleh 23 orang pada hari pertama dan 30 orang pada hari kedua. Kegiatan ini dilakukan dengan ceramah, diskusi, dan tanya jawab. Kegiatan pelatihan dilaksanakan selama dua hari Jumat 28 Juni 2013 dan 29 Juni 2013. Kegiatan ini terbagi ke dalam 4 (empat) sesi. Kegiatan Pelatihan Peran Kader Posyandu dalam Deteksi Perkembangan Anak Usia Dini ini mampu memberikan beberapa alternatif penyelesaian masalah yang terjadi ketika kegiatan Posyandu berlangsung di wilayah Kecamatan Pleret Bantul.
\end{abstract}

Kata Kunci: pelatihan, kader Posyandu, deteksi perkembangan, anak

\begin{abstract}
The efforts to observe the early child's growth and development were the main duty of family and helped by the Posyandu. Posyandu held on each village by the officer or cadre that already given the knowledge and training to socialized health knowledge for the parents, especially about child's growth and development. The common activities on Posyandu were weight scaling and nutrition supplementation, that's why Posyandu usually focused on physical growth. Thereby, there were some needs to give more knowledge about early detection of child's development, so that prevention action could be given to solve the obstacles of development. This training followed by 23 participants on the first meeting and 30 participants on the second meeting. The training methods were speech, discussion, and debriefing. The training activity held twice on 28-29 June 2013. This activity divided into four sessions. This activity could give some alternatives to solve the problems that occurred on some Posyandu at Kecamatan Pleret Bantul.
\end{abstract}

Keywords: training, Posyandu cadre, growth detection, child

\section{PENDAHULUAN}

Upaya pemantauan tumbuh kembang anak usia dini secara pokok merupakan tugas keluarga. Hal ini karena keluarga merupakan lingkungan terdekat dengan anak yang mengetahui dengan pasti perjalanan tumbuh kembang anak. Keluarga juga merupakan lingkungan tempat anak menghabiskan waktu. Sejak anak dilahirkan pertama kali bersentuhan dengan anggota keluarga. anak belajar tentang lingkungan terdekatnya dimulai dari mengamati perilaku anggota keluarga. Namun, tidak semua keluarga dapat melaksanakan tugas pemantauan tumbuh kembang anak secara optimal. Kesibukan, kurangnya pengetahuan, dan keadaan ekonomi-sosial keluarga dapat menjadi faktor yang tidak mendukung upaya pemantauan tumbuh kembang anak usia 
dini. Oleh karena itu, selama ini pemantauan pertumbuhan dan perkembangan anak dikoordinasi melalui peran masyarakat melalui program Posyandu.

Program Posyandu dilakukan di setiap desa oleh kader yang telah diberi pengetahuan dan pelatihan oleh para petugas kesehatan. Tujuan penggunaan kader sebagai pelaksana Posyandu adalah untuk memasyarakatkan pengetahuan tentang kesehatan, terutama pertumbuhan dan perkembangan anak. Umumnya kegiatan Posyandu meliputi kegiatan penimbangan balita dan pemberian nutrisi, sehingga sebagai sasaran utama Posyandu lebih tertuju pada tahap pertumbuhan fisik saja. Deteksi dini untuk mengetahui hambatan perkembangan anak juga belum diberikan, sehingga tindakan preventif untuk mengatasi adanya gangguan perkembangan pada balita belum dilakukan. Di sisi lain, perkembangan psikis anak juga masih kurang diperhatikan, misalnya cara orang tua memberikan penguatan pada anak, pola asuh terhadap anak dan sebagainya. Padahal aspek fisik dan psikis saling mempengaruhi dalam proses tumbuh kembang anak. Terganggunya salah satu faktor akan mempengaruhi faktor lainnya. Selain itu, pemberian pengetahuan pada orang tua tentang cara menstimulasi perkembangan anak juga belum diberikan di Posyandu. Padahal sebagian orang tua belum mampu memberikan stimulasi pada anak. Orang tua beranggapan "yang penting anak diam dan tidak rewel". Tanpa adanya stimulasi yang tepat, dapat menghambat proses tumbuh kembang anak. Oleh karena itu untuk mengoptimalkan pemantauan perkembangan anak perlu diadakan pelatihan bagi para kader Posyandu dalam deteksi tumbuh kembang anak usia dini.

\section{Identifikasi Masalah}

Identifikasi masalah dalam kegiatan ini adalah:
1. Kegiatan Posyandu yang dilaksanakan selama ini masih monoton pada pemantauan pertumbuhan anak.

2. Kegiatan Posyandu yang dilaksanakan selama ini tidak memperhatikan perkembangan psikologis anak.

\section{Perumusan Masalah}

Perumusan masalah dalam kegiatan ini adalah:

1. Bagaimana meningkatkan pengetahuan kader Posyandu mengenai tumbuh kembang anak usia dini?.

2. Bagaimana meningkatkan pengetahuan dan keterampilan kader Posyandu dalam stimulasi tumbuh kembang anak usia dini ?.

3. Bagaimana meningkatkan pengetahuan dan keterampilan kader Posyandu dalam deteksi dini terhadap hambatan tumbuh kembang anak usia dini ? .

\section{Anak Usia Dini}

Usia dini berawal dari akhir masa bayi (2 tahun) sampai usia 5 atau 6 tahun (Santrock, 2007). Pada usia ini, anak mengalami pertumbuhan dan perkembangan yang mempersiapkan mereka pada usia akademik atau usia sekolah. Mereka mengembangkan kemandirian, bermain dengan teman, mengenal huruf, dan mengalami pertumbuhan motorik halus dan kasar. Oleh karena itu, usia dini disebut juga 'preschool years'.

Seluruh aspek pada diri anak berkembang pada usia dini. Aspek-aspek tersebut adalah:

1. Perkembangan Kognitif

Jean Piaget, seorang pakar psikologi yang terkenal dengan teori perkembangan kognitifnya, menyebut usia dini dengan tahap pra-operasional (pre-operational stage). Karakteristik dari tahap pra-operasional oleh Papalia, dkk. (2002) disimpulkan terdiri dari dua wilayah karakteristik, yaitu kelebihan dan kekurangan. Kelebihan pada tahap berpikir pra- 
operasional meliputi berkembangnya: a) fungsi simbolik yang diiringi oleh tumbuhnya pemahaman terhadap ruang, kausalitas, identitas, kategorisasi dan angka; b) Pemahaman terhadap identitas, yakni anak dapat memahami bahwa penggantian penampakan sesuatu tidak mengubah hakikat benda tersebut yang sesungguhnya.; c) Pemahaman terhadap sebab dan akibat: anak mengerti bahwa setiap kejadian memiliki penyebab; d) Kemampuan untuk membuat klasifikasi: anak mampu mengatur objek, orang, dan kejadian ke dalam kategorisasi yang berarti; e) Pemahaman terhadap angka: anak mampu berhitung dan berhubungan dengan kuantitas; f) Empati: anak menjadi lebih mampu untuk membayangkan bagaimana kemungkinan perasaan orang lain dan; g) Teori Akal: anak menjadi lebih sadar terhadap aktivitas mental dan fungsi pikiran.

Adapun kekurangan pada tahap pra-operasional meliputi perhatiannya yang terpusat, irreversibilitas atau kegagalan memahami fakta yang berkebalikan, fokus pada keadaan yang tetap daripada perubahan bentuk, penalaran transduktif atau melompat dari satu fakta ke fakta lain, egosentrisme, animisme, dan ketidakmampuan untuk membedakan penampakan dengan kenyataan.

2. Perkembangan Emosi

Anak usia dini mulai belajar untuk mengenali emosinya. Saarni, dkk. (seperti dikutip oleh Papalia, dkk., 2002) menyatakan bahwa anak usia dini dapat membicarakan perasaan mereka dan dapat melihat perasaan orang lain. Anak usia dini dapat memahami bahwa emosi-emosi tersebut berhubungan dengan pengalamanpengalaman dan keinginan-keinginan. Namun demikian, mereka masih belum dapat memahami secara utuh terhadap beberapa emosi yang berhubungan langsung dengan diri sendiri seperti malu dan bangga. Selain itu, anak usia dini menemui kesulitan untuk mendamaikan beberapa emosi yang berlawanan, seperti merasa bahagia mendapatkan sepeda baru, tetapi merasa kecewa karena warnanya tidak sesuai yang diinginkan (Kestenbaum \& Gelman dalam Papalia, dkk., 2002). Menurut Papalia, dkk. (2002), emosiemosi yang langsung berhubungan dengan diri sendiri seperti malu dan bangga, berkembang selama tahun ketiga, setelah anak memiliki kesadaran diri (selfawareness). Emosi-emosi ini tergantung pada penanaman standar perilaku oleh orangtua.

Penelitian yang dilakukan oleh Harter (dalam Papalia, dkk., 2002) menemukan bahwa perkembangan emosi pada anak-anak terjadi secara bertahap. Penelitian tersebut melibatkan anak yang berusia antara 4 sampai 8 tahun, anak-anak tersebut dibacakan dua buah cerita. Cerita pertama, seorang anak mengambil beberapa uang receh dari kotak setelah diberitahu ia tidak boleh mengambil uang receh tersebut. Cerita kedua, seorang anak menampilkan sebuah atraksi senam yang sulit, yaitu salto di atas sebuah papan. Masing-masing cerita ditampilkan dengan dua versi, salah satunya orangtua melihat aksi anak tersebut dan versi lain tidak ada seorang pun yang melihat perilaku anak tersebut. Anak-anak dalam penelitian tersebut diminta menyatakan bagaimana perasaannya dan perasaan orangtua pada masing-masing keadaan tersebut.

Anak usia 4-5 tahun tidak menyatakan apakah dirinya atau orangtua merasa bangga atau malu. Mereka justru menggunakan istilah seperti "cemas" atau "takut" (pada insiden anak mengambil koin) dan "menyenangkan" atau "bahagia" ( pada atraksi senam). Anak usia 5-6 tahun menyatakan bahwa orangtua mereka akan merasa malu atau bangga, tetapi anak-anak tidak mengetahui apakah mereka sendiri merasakan emosi tersebut. Anak usia 6-7 
tahun menyatakan bahwa mereka akan merasa bangga atau malu, hanya jika mereka diamati. Anak usia 7-8 tahun memahami bahwa ada atau tidak orang lain yang mengamati mereka, mereka akan merasa malu atau bangga.

3. Perkembangan Psikososial

Menurut Erik H. Erikson, tahap psikososial yang terjadi pada anak usia dini karakteristiknya adalah inisiatif lawan perasaan bersalah. Pada usia dini, inisiatif anak berkembang pesat, banyak hal yang anak-anak ingin lakukan. Tetapi orangtua dan orang dewasa lainnya menyatakan bahwa anak-anak tidak dapat melakukan segala sesuatu yang mereka inginkan. Pada kondisi seperti inilah, menurut Erikson, muncul krisis antara inisiatif lawan perasaan bersalah, yaitu pada satu sisi ada hal-hal yang ingin dilakukan, tetapi pada sisi lain terdapat larangan dari orang dewasa di sekitar anak-anak (Steinberg, dkk., 1991).

4. Perkembangan Motorik

Perkembangan motorik kasar anak usia dini sangat pesat. Mereka senang menjelajah sejalan dengan perkembangan motoriknya yang semakin baik. Anak-anak usia dini sangat aktif, lebih aktif dibanding tahap-tahap perkembangan lainnya (Santrock, 1999). Adapun motorik halus juga berkembang secara substantif pada tahap usia dini. Anak usia 3 tahun telah dapat memegang benda-benda ramping diantara ibu jari dan telunjuknya, tetapi mereka masih kikuk. Ketika anak usia 3 tahun bermain puzzle sederhana, mereka akan menempatkan kepingan-kepingan puzzle secara kasar. Anak usia 4 tahun mengalami perkembangan motorik halus secara substantif lebih meningkat. Misalnya anak mengalami kesulitan untuk membangun balok-balok menjadi sebuah menara, mereka mungkin mengalami kesulitan karena ingin membuatnya secara sempurna dan merasa putus asa. Anak usia 5 tahun memiliki perkembangan motorik halus yang lebih meningkat. Tangan, lengan dan tubuh, semuanya bergerak bersama dibawah koordinasi mata (Santrock, 1999).

\section{Deteksi Perkembangan Anak Usia Dini}

Deteksi perkembangan anak usia dini atau deteksi dini merupakan upaya penjaringan yang dilaksanakan secara komprehensif untuk menemukan penyimpangan tumbuh kembang dan mengetahui serta mengenal faktor resiko (fisik, biomedik, psikososial) pada balita, yang disebut juga anak usia dini (Tim Dirjen Pembinaan Kesmas, 1997). Kegunaan deteksi dini adalah untuk mengetahui penyimpangan tumbuh kembang anak secara dini, sehingga upaya pencegahan, upaya stimulasi, dan upaya penyembuhan serta pemulihan dapat diberikan dengan indikasi yang jelas sedini mungkin pada masa-masa kritis proses tumbuh kembang. Upaya-upaya tersebut diberikan sesuai dengan umur perkembangan anak, dengan demikian dapat tercapai kondisi tumbuh kembang yang optimal ((Tim Dirjen Pembinaan Kesmas, 1999).

Alat untuk deteksi dini berupa tes skrining yang telah distandardisasi untuk menjaring anak yang mempunyai kelainan dari mereka yang normal ((Tim Dirjen Pembinaan Kesmas, 1997). Tes skrining yang peka, dapat meramalkan keadaan anak dikemudian hari. Oleh sebab itu diperlukan kepekaan dari petugas yang melakukan deteksi dini, dalam hal ini kader Posyandu. Menurut Pedoman Deteksi Dini Tumbuh Kembang Balita (Tim Dirjen Pembinaan Kesmas, 1997) macam-macam tes skrining yang digunakan adalah: pengukuran Berat Badan menurut Umur (BB/ U); Pengukuran Lingkaran Kepala Anak (PLKA); Kuesioner Pra Skrining Perkembangan (KPSP) yang ditujukan pada orangtua; Kuesioner Perilaku Anak Prasekolah (KPAP); Tes Daya Lihat (TDL); dan Tes Kesehatan Mata (TKM) bagi Anak Prasekolah. 


\section{Peran Kader Posyandu dalam Deteksi Perkembangan Anak}

Posyandu merupakan suatu kegiatan masyarakat, oleh masyarakat, dan untuk masyarakat dengan memakai sistem lima meja (Meja 1: Pendaftaran, Meja 2: Penimbangan, Meja 3: Pencatatan Hasil Penimbangan, Meja 4: Penyuluhan, Meja 5: Pelayanan Kesehatan dan Keluarga Berencana) yang memberikan lima pelayanan yaitu: Pelayanan Gizi, Kesehatan Ibu dan Anak (KIA), Keluarga Berencana (KB), Penanggulangan Diare, dan Pelayanan Imunisasi.

Saat ini berkembang menjadi Posyandu Plus yang merupakan rujukan mitra keluarga yang menghasilkan lima pelayanan di Posyandu dengan penambahan (plus) pada pelayanan konseling mitra keluarga serta pengaturan waktu buka (pelayanan) yang fleksibel sesuai dengan kebutuhan masyarakat. Sasaran dari Posyandu Plus adalah seluruh anggota keluarga yang terdiri dari: 1) Keluarga baru; 2) Keluarga ibu hamil, melahirkan, dan menyusui; 3) Keluarga bayi dan balita; 4) Keluarga anak usia sekolah dan remaja; 5) Keluarga usia subur; dan 6) Keluarga usia lanjut (Tim Pengembangan Posyandu Plus Propinsi DIY, 2006).

Menurut Tim Konsep Pengembangan Posyandu Plus Propinsi DIY (2006), Posyandu diselenggarakan oleh masyarakat sendiri dengan bimbingan dan pembinaan dari petugas lintas sektor terkait. Anggota masyarakat yang dilatih dan dibina ini disebut dengan istilah kader. Selama ini pelatihan dan pembinaan kader dilakukan oleh Dinas Kesehatan melalui Puskesmas setempat, dengan demikian fokus pelatihan dan pembinaan hanya ditekankan pada bidang kesehatan. Dalam pengembangannya menjadi Posyandu Plus, pelatihan dan pembinaan kader tidak hanya akan difokuskan pada bidang kesehatan saja tetapi juga akan meliputi bidang hukum, sosial, ekonomi, pendidikan, dan psikologi.

\section{Khalayak Sasaran}

Khalayak sasaran yang dituju dalam pelatihan ini adalah kader Posyandu di wilayah Kecamatan Pleret Bantul berjumlah 30 kader.

\section{METODE KEGIATAN}

Kegiatan dilaksanakan dalam bentuk ceramah, diskusi, studi kasus, dan simulasi. Metode ceramah digunakan dalam mentransfer pemahaman peserta tentang perkembangan anak usia dini, stimulasi perkembangan dan deteksi kebutuhan khusus pada anak usia dini. Metode diskusi dilaksanakan untuk memperkuat pemahaman anak selama ceramah. Metode studi kasus digunakan untuk menelaahan kasus yang ditemukan oleh Kader Posyandu di wilayah kerja masing-masing. Adapun metode simulasi digunakan untuk materi yang berkenaan dengan praktik, seperti stimulasi dan deteksi dini.

\section{Langkah-Langkah Kegiatan}

meliputi:

Langkah-langkah kegiatan

1. Program Studi Pendidikan Anak Usia Dini (PGPAUD) bekerjasama dengan Jurusan Pendidikan Luar Biasa dan Fakultas Ilmu Pendidikan Universitas Negeri Yogyakarta. Beberapa dosen terkait dilibatkan sebagai narasumber, trainer, atau instruktur dalam pelatihan ini.

2. Puskesmas Pleret Kabupaten Bantul yang mengkoordinasi Kader Posyandu se kecamatan Pleret Kabupaten Bantul, yang berperan dalam fasilitasi forum.Peserta merupakan delegasi kader Posyandu dari tiap desa.

3. Mahasiswa Program Studi PGPAUD FIP UNY dilibatkan dalam bentuk partisipasi dalam membantu pelaksanaan kegiatan.

\section{HASIL PELAKSANAAN KEGIATAN}

Program Pelatihan Peran Kader Posyandu ini dilaksanakan dengan 
melibatkan kader Posyandu di wilayah Kecamatan Pleret Bantul telah diikuti oleh 21 orang pada hari pertama dan 30 orang pada hari kedua. Kegiatan ini dilakukan dengan ceramah, diskusi, studi kasus dan simulasi. Kegiatan pelatihan dilaksanakan selama dua hari yaitu hari Jumat 28 Juni 2013 dan Sabtu 29 Juni 2013. Kegiatan ini terbagi ke dalam 3 (tiga) sesi. Adapun deskripsi pelaksanaan kegiatan pelatihan sebagai berikut:

1. Sesi Pertama

Pelaksanaan sesi pertama ini dilaksanakan pada tanggal 28 Juni 2013 diisi dengan ceramah yang berjudul Perkembangan Anak Usia Dini. Ceramah ini disampaikan oleh Ibu Muthmainnah, M.Pd., yang memang memiliki keahlian di bidang terkait. Perlunya diberikan pelatihan ini agar kader Posyandu memahami hakikat tumbuh kembang anak sebagai landasan dalam memberikan layanan Posyandu. Dengan memahami perkembangan anak usia dini, diharapkan kader Posyandu mampu memberikan layanan tumbuh kembang anak secara optimal. Strategi dan metode yang dipilih dapat digunakan untuk mengoptimalkan potensi kader Posyandu mengenai tahap perkembangan anak.

2. Sesi Kedua

Pelaksanaan sesi kedua ini diisi dengan ceramah yang berjudul "Stimulasi Perkembangan Anak Usia Dini". Ceramah ini disampaikan oleh Ibu Nur Hayati, M.Pd yang memang memiliki keahlian di bidang terkait. Perlunya diberikan penyuluhan ini agar kader Posyandu memahami tentang stimulasi yang tepat sesuai perkembangan anak usia dini. Pengetahuan ini dapat dijadikan landasan untuk meningkatkan kemampuan kader Posyandu dalam memantau perkembangana anak. Prinsip stimulasi yang diberikan dengan bermain melibatkan semua aspek perkembangan anak usia dini yaitu aspek kognitif, fisik, bahasa dan sosial emosional.

3. Sesi Ketiga

Pelaksanaan sesi ketiga dilaksanakan pada hari Sabtu 29 Juni 2013. Kegiatan ini diisi dengan ceramah yang berjudul "Deteksi Kebutuhan Khusus pada AUD". Ceramah ini disampaikan oleh Ibu Aini Mahabbati, M.A yang memang memiliki keahlian di bidang terkait. Perlunya diberikan penyuluhan ini agar kader Posyandu memahami tentang kondisi khusus yang terjadi pada anak terutama yang berkebutuhan khusus pada anak usia dini. Pengetahuan ini dapat dijadikan landasan untuk mendeteksi apakah ada anak berkebutuhan khusus yang perlu mendapatakan perhatian serta penanganan ahli. Dengan pengetahuan sedini mungkin, maka anak berkebutuhan khusus yang ada di lingkungan Posyandu dapat tertangani dengan baik dan optimal.

4. Sesi Keempat

Kegiatan sesi keempat ini diisi dengan simulasi tumbuh kembang anak serta diskusi tentang penanganan anak berkebutuhan khusus. Kegiatan simulasi tumbuh kembang berpedoman pada tes Denver untuk mencermati perkembangan anak tiap tahap usia dan dilanjutkan deteksi awal anak berkebutuhan khusus. Kegiatan ini dipandu oleh Ibu Aini Mahabbati, M.A dan Ibu Nur Hayati, M.Pd. Kegiatan ini dibagi ke dalam beberapa termin pertanyaan. Antusiasme peserta dalam kegiatan ini cukup baik. Beberapa peserta yang hadir sebagai kader Posyandu serta kader PAUD merasa kesulitan untuk menerapkan stimulasi perkembangan AUD dan deteksi anak berkebutuhan khusus. Keterbatasan tersebut cukup wajar, karena banyak kader Posyandu yang memberikan layanan tumbuh kembangan anak tidak 
berdasarkan pada teori perkembangan anak. Sehingga banyak yang memberikan layanan dengan caranya sendiri dan dengan keterbatasan ilmu serta pengalaman. Setelah melalui beberapa diskusi, mulai ditemukan beberapa cara efektif untuk memberikan stimulasi yang tepat pada anak usia dini secara bertahap. Dari kegiatan ini diharapkan masalahmasalah yang dihadapi peserta kegiatan pelatihan ini dapat terselesaikan berdasarkan penjelasan dari narasumber.

\section{PEMBAHASAN}

Peran kader Posyandu di setiap desa sangat penting dalam memantau tumbuh kembang anak usia dini. Pengetahuan tentang perkembangan anak usia dini menjadi bekal dalam melaksanakan kegiatan Posyandu. Kader Posyandu dapat mengamati perkembangan anak setiap bulan sehingga dapat memberikan stimulasi yang tepat bagi anak yang datang ke Posyandu. Stimulasi yang diberikan kader Posyandu dalam bentuk kegiatan bermain ketika anak menunggu giliran untuk di timbang maupun setelah ditimbang. Setelah mempunyai bekal pengetahuan mengenai perkembangan anak usia dini berta stimulasi yang tepat, maka kader Posyandu dapat mengetahui adanya penyimpangan tumbuh kembang anak secara dini, sehingga upaya pencegahan, upaya stimulasi, dan upaya penyembuhan serta pemulihan dapat diberikan dengan indikasi yang jelas sedini mungkin pada masa-masa kritis proses tumbuh kembang.

Para kader Posyandu di Kecamatan Pleret awalnya belum mempunyai pengetahuan yang banyak mengenai perkembangan anak usia dini. Beberapa hari setelah mengikuti pelatihan dapat memberikan stimulasi yang sesuai dengan tahapan perkembangan anak usia dini. Kader Posyandu yang awalnya belum mengerti jika ada standar pengamatan perkembangan anak, perlahan setelah mendapatkan materi mereka dapat mempelajari dan mengimplementasikan stimulasi bagi anak usia dini. Kader Posyandu juga memahami dalam memperlakukan anak yang berkebutuhan khusus sesuai dengan kondisi anak serta standar yang telah ditentukan.

Berdasarkan hasil penyebaran angket tentang perkembangan anak usia dini serta deteksi anak berkebutuhan khusus dapat disimpulkan bahwa $57 \%$ kader Posyandu sudah memahami tentang stimulasi perkembangan anak usia dini. 46\% Kader Posyandu memahami deteksi awal tentang anak berkebutuhan khusus. Hasil angket berikutnya menyatakan $90 \%$ peserta merasa puas dan memahami materi yang disampaikan oleh pemateri. Namun demikian pengembangan pemantauan tumbuh kembang anak akan berhasil jika mendapatkan dukungan dan kerjasama dari masyarakat dan puskesmas. Kerjasama yang masif dari semua pihak terkait dapat mengoptimalkan peran Posyandu yang ada di setiap desa khususnya di wilayah Kecamatan Pleret.

Adapun faktor pendukung kegiatan ini adalah adanya kerjasama antar anggota TIM PPM serta adanya kerja sama dengan Puskesmas Pleret serta kader Posyandu di wilayah Kecamatan Pleret Bantul. Kader Posyandu yang kami undang adalah delegasi dari Posyandu-Posyandu yang ada di setiap desa sekecamatan Pleret Bantul. Tempat serta fasilitas kegiatan didukung sepenuhnya oleh Kepala Puskesmas Pleret yang bekerja sama dengan Fakultas Ilmu Pendidikan UNY dalam hal ini diwakili oleh dosen PGPAUD dan dosen PLB FIP UNY selaku tim pelaksana kegiatan PPM. Sedangkan faktor penghambat kegiatan ini adalah jumlah peserta yang hadir ketika acara penyuluhan berlangsung tidak sesuai dengan yang diperkirakan tim PPM semula 30 orang pada hari pertama yang hadir hanya 21 orang karena banyak kader Posyandu yang ada acara bersamaan 
dengan pelaksanaan PPM. Namun pada hari kedua bisa hadir 30 orang peserta.

\section{PENUTUP}

Kegiatan Pelatihan Peran Kader Posyandu dalam Deteksi Perkembangan Anak Usia Dini ini mampu memberikan beberapa alternatif penyelesaian masalah yang terjadi ketika kegiatan Posyandu berlangsung di wilayah Kecamatan Pleret Bantul. Dengan adanya pelatihan ini dapat memberikan wawasan tentang pentingnya stimulasi yang tepat pada anak khususnya jika dideteksi ada anak berkebutuhan khusus.

\section{DAFTAR PUSTAKA}

Hurlock, E. B. (1980). Psikologi Perkembangan: Suatu Pendekatan Sepanjang Rentang Kehidupan. Edisi Kelima. (Alih Bahasa: Istiwidayati \& Soejarwo. Jakarta: Penerbit Erlangga.

Papalia, D.E., Olds, S.W. \& Feldman, R.D. (2002). A Child's World: Infancy through Adolescence. $9^{\text {th }}$ ed. New York: McGraw-Hill Companies, Inc.

Santrock, J. W. (2007). Child Development (11 ed.). (M. Rachmawati, \& A. Kuswanti, Trans.) Jakarta: Penerbit Erlangga.

Santrock, J.W. (1999). Life-Span Development. $7^{\text {th }}$ ed. Boston: McGrawHill College.

Steinberg, L., Belsky, J. \& Meyer, R.B. (1991). Infancy, Childhood \& Adolescence: Development in Context. New York: McGraw-Hill, Inc.

Tim Dirjen Pembinaan Kesmas. (1997). Pedoman Deteksi Dini Tumbuh
Kembang Balita. Jakarta: Departemen Kesehatan RI.

Tim Pengembangan Posyandu Plus Propinsi DIY. (2006). Konsep Pengembangan Posyandu Plus. Yogyakarta: Pemerintah Propinsi DIY. 